Article

\title{
Semi-Synthesis of C-Ring Cyclopropyl Analogues of Fraxinellone and Their Insecticidal Activity Against Mythimna separata Walker
}

\author{
Xiao-Jun Yang ${ }^{1}$, Qing-Miao Dong ${ }^{2}$, Min-Ran Wang ${ }^{2}$ and Jiang-Jiang Tang ${ }^{2, *(\mathbb{D})}$ \\ 1 School of Chemistry \& Chemical Engineering, Yanan University, Yanan 716000, China; \\ yangxiaojun2002@126.com \\ 2 Shaanxi Key Laboratory of Natural Products \& Chemical Biology, College of Chemistry \& Pharmacy, \\ Northwest A\&F University, Yangling 712100, China; qingmiaodong@nwafu.edu.cn (Q.-M.D.); \\ 13833683803@163.com (M.-R.W.) \\ * Correspondence: tangjiang11@nwafu.edu.cn; Tel.: +86-2987-09-2662
}

Received: 31 January 2020; Accepted: 28 February 2020; Published: 2 March 2020

\begin{abstract}
Fraxinellone (1) is a naturally occurring degraded limonoid isolated from Meliaceae and Rutaceae plants. As a potential natural-product-based insecticidal agent, fraxinellone has been structurally modified to improve its activity. Furan ring of fraxinellone is critical in exhibiting its insecticidal activity, but with few modifications. Herein, C-ring-modified cyclopropyl analogues were semi-synthesized by $\mathrm{Rh}(\mathrm{II})$-catalyzed cyclopropanation. The structures of the target compounds were well characterized by NMR and HRMS. The precise three-dimensional structural information of 3a was established by X-ray crystallography. Their insecticidal activity was evaluated against Mythimna separata Walker by a leaf-dipping method. Compound 3c exhibited stronger insecticidal activity than $\mathbf{1}$ and toosendanin against $M$. separata with teratogenic symptoms during the different periods, implying that cyclopropanation of the furan ring could strengthen the insecticidal activity of fraxinellone.
\end{abstract}

Keywords: fraxinellone; insecticidal agent; cyclopropanation

\section{Introduction}

Natural products (NPs) continue to provide a rich source for drug discovery [1-8]. In the past decades of controlling agricultural pests, NPs also played a key role in the discovery of novel pesticides owing to their potential target sites, low toxicity, and environment-friendly characteristics [4-8]. In order to improve the hit rate, NPs were always synthesized with diverse structures in a screening molecules library [9].

Fraxinellone (1, Figure 1) containing three rings (labeled A-C) is a degraded limonoid isolated from barks and roots of Dictamnus dasycarpus Turcz. and exhibits interesting insecticidal activity $[10,11]$. The activity relationships of fraxinellone showed that the furan ring (C-ring) is essential for its insecticidal activities [12]. Several NPs examples with the furan ring as an important pharmacophore exhibit various bioactivities [4,13-17]. For example, toosendanin (Figure 1) showed potent antifeedant and growth inhibitory effects against armyworm Mythimna separata and cutworm Peridroma saucia, in which the furan ring is critical $[16,17]$.

To improve the agrochemical activities of fraxinellone, structural modifications of its A-ring and B-ring have been carried out by $\mathrm{Xu}$ group [18], and some fraxinellone-based esters and hydrazones analogues at C-4/C-10 position (A-ring) displayed stronger insecticidal activities against Mythimna separata Walker and Plutella xylostella Linnaeus. However, the furan ring of fraxinellone 
remains with few modifications. Recently, the modification of aromatic (furan ring) functionalities was reported by us $[19,20]$. A series of C-ring selective brominations and further palladium-catalyzed transformations analogues of fraxinellone have been prepared. To our delight, some compounds displayed more potent insecticidal activity than toosendanin. On the basis of the above furan-modified results and in our endeavor aiming at finding more active natural-product-based insecticidal hits [19,21-24], herein, we semi-synthesized C-ring cyclopropyl analogues of fraxinellone by $\mathrm{Rh}$ (II)-catalyzed cyclopropanation as insecticidal agents against $M$. separata.
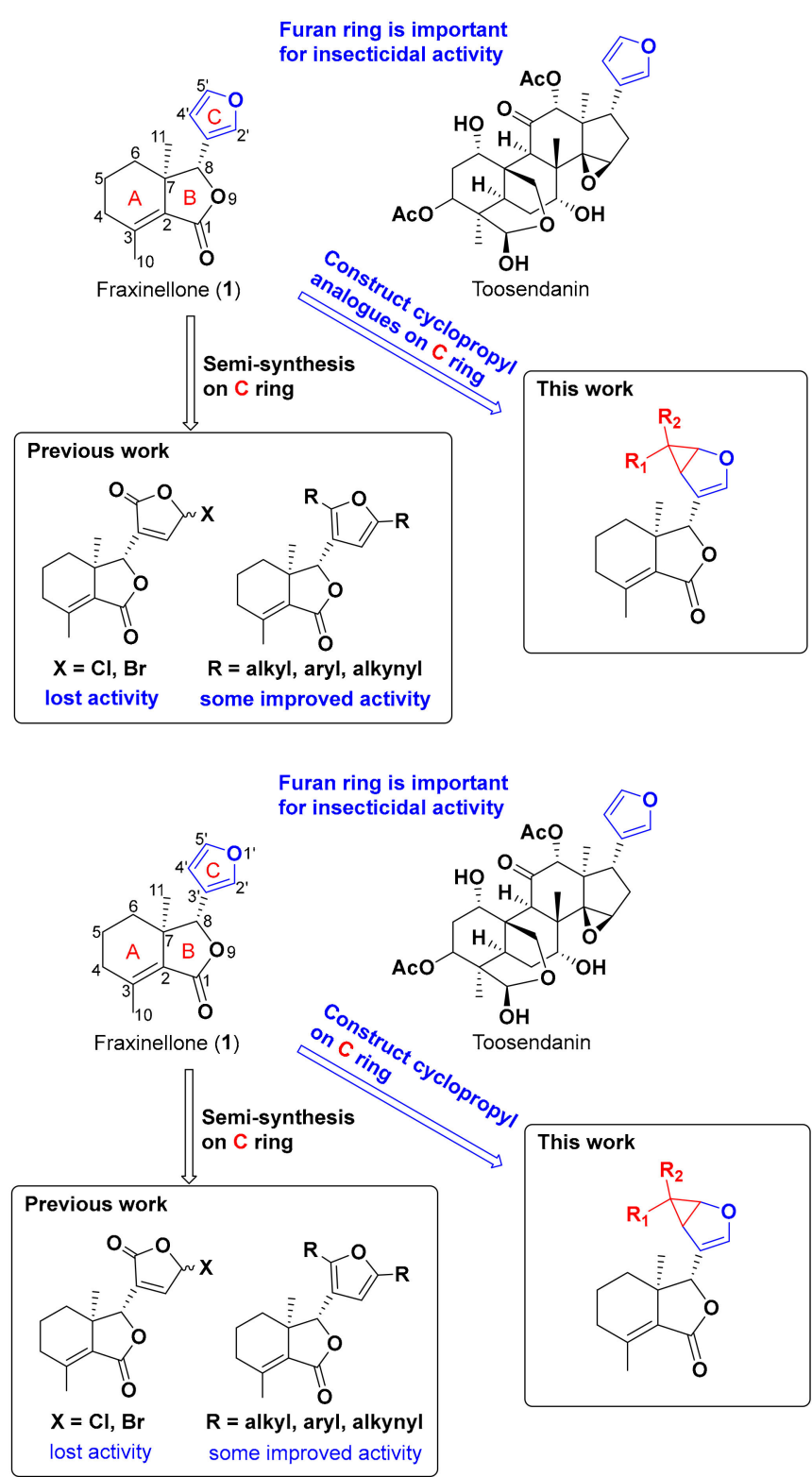

Figure 1. Chemical structures of fraxinellone (1) and its furan-modified analogues, and toosendanin.

\section{Results and Discussion}

\subsection{Semi-Synthesis}

An attractive approach to utilize the furan ring for the generation of resourceful analogues is the $[2+1]$ addition of carbenes $[25,26]$. As shown in Scheme 1, the commercial substrate aromatic ethyl esters firstly reacted with $p$-toluenesulfonyl azide $\left(\mathrm{TsN}_{3}\right)$ to form $\alpha$-carbonyldiazoesters $(2 \mathbf{a}-2 \mathbf{c})$ in the presence of base 1,8-diazabicyclo[5.4.0]undec-7-ene (DBU) in high yields (67-90\%). 
Yet, when trimethylamine $\left(\mathrm{Et}_{3} \mathrm{~N}\right)$ was used as the base, this reaction did not occur. If methyl 2-thiophene acetate was used to react with $\mathrm{TsN}_{3}$ under the above reaction conditions, the target compound cannot be prepared.

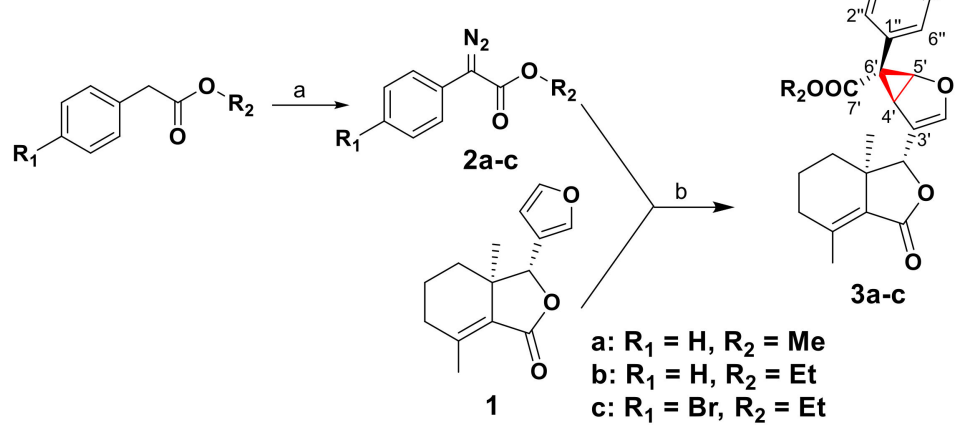

Scheme 1. Synthesis of fraxinellone C-ring cyclopropyl analogues (3a-3c). Reagents and conditions: (a) $\mathrm{TsN}_{3}$ (1.2 equiv), 1,8-Diazabicyclo[5.4.0] undec-7-ene (DBU) (1.5 equiv), MeCN, $25^{\circ} \mathrm{C}, 15 \mathrm{~h}, 67-90 \%$ isolated yields; (b) $\mathrm{Rh}_{2}(\mathrm{OAc})_{4}\left(0.01\right.$ equiv), $\mathrm{PhMe}, 0{ }^{\circ} \mathrm{C}, 13 \mathrm{~h}, 3 \mathrm{a}: 20 \%, 3 \mathbf{b}: 37 \%, 3 \mathrm{c}: 10 \%$ isolated yields.

With acceptor diazoesters (2a-2c) in hand, fraxinellone (1) as a starting brick was converted into the corresponding monocyclopropanated adducts (3a-3c). $\mathrm{Rh}_{2}(\mathrm{OAc})_{4}$-catalyzed cyclopropanation of 1 mainly provides stereoselective adducts by thin-layer chromatography (TLC) isolation. The absolute configuration of 3a was unambiguously established by X-ray crystallography (Figure 2), indicating the cyclopropyl ring of $4^{\prime}$ and $5^{\prime}$ positions was formed in $\beta$ configuration of the furan ring. Formation of this product can be rationalized on steric ground in the asynchronous concerted cyclopropanation that the reaction of the Rh-bound carbene occurs from the si face of the carbene [27,28]. Using the same orientation of attack, the observed stereochemistry is consistent with the attack occurring at the $\beta$-position for $\mathbf{3 b}$ and $\mathbf{3} \mathbf{c}$ in NOE spectra. Furthermore, the configuration of $\mathbf{3 a}$ indicated the top chiral carbon of the cyclopropyl ring oriented the ester group onto the convex face of the bicycle, which is same as synthetic methodology [29]. Unfortunately, the yields were too low (10-37\%), with just 50-60\% conversion of diazoesters and about $70 \%$ conversion of fraxinellone, perhaps because of the complexity of the fraxinellone structure. The structures of all analogues were determined by NMR and HRMS and were stable for at least five days in solid or in acetone solution at room temperature. Their spectra can be found in the Supplementary Materials.

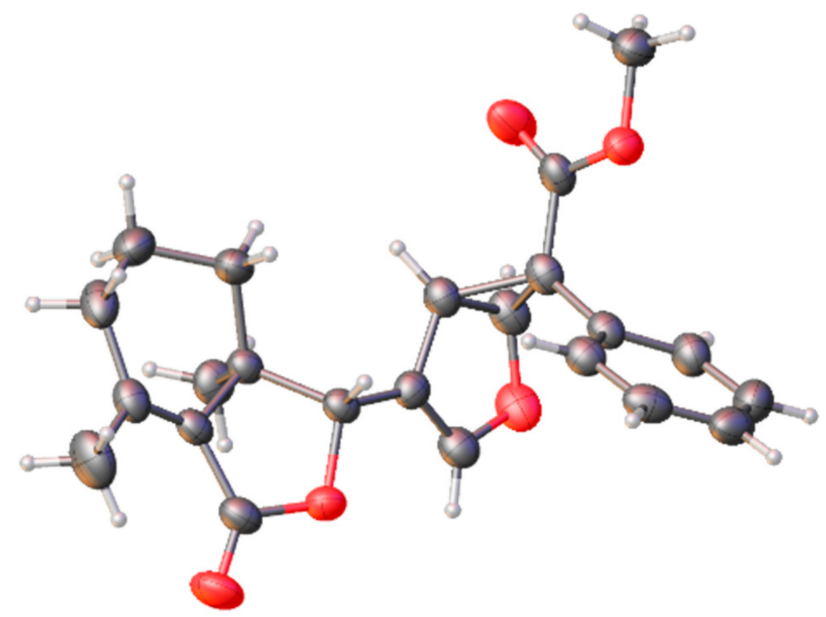

Figure 2. X-ray crystal structure of compound 3a (CCDC number: 1549251 at https://www.ccdc.cam.ac.uk). 


\subsection{Insecticidal Activity}

The insecticidal activity of all cyclopropanated analogues was tested against M. separata Walker by the leaf-dipping method as the mortality rates at $1 \mathrm{mg} / \mathrm{mL}$ [30]. Toosendanin, a commercial natural-product-based insecticide, was used as a positive control and leaves treated with acetone alone were used as a blank group. The corrected mortality rate at different stages was outlined in Table 1. Fraxinellone and its prepared analogues exhibited the delayed insecticidal activity against $M$. separata. For example, the mortality rates of 3a against $M$. separata after 10 and 20 days were $8.3 \%$ and $12.5 \%$, respectively. However, it was increased to $29.2 \%$ after 35 days with over three-fold of that after 10 days. Among all tested analogues, $3 \mathrm{c}$ displayed stronger insecticidal activity than their precursor $\mathbf{1}$ and toosendanin. The final mortality rates of $3 \mathbf{c}$ were $34.5 \%$, whereas the final mortality rates of $\mathbf{1}$ and toosendanin were $17.4 \%$ and $33.3 \%$, respectively.

Table 1. Insecticidal activity of fraxinellone C-ring cyclopropyl analogues $3 \mathbf{a}-\mathbf{3 c}$ against $M$. separata on leaves treated with a concentration of $1 \mathrm{mg} / \mathrm{mL}$.

\begin{tabular}{cccc}
\hline \multirow{2}{*}{ Compound } & \multicolumn{3}{c}{ Corrected Mortality Rate $[\%]^{\mathbf{1}}$} \\
\cline { 2 - 4 } & 10 days & 20 days & 35 days \\
\hline $\mathbf{1}$ & 0.0 & 11.3 & 17.4 \\
$\mathbf{3 a}$ & 8.3 & 12.5 & 29.2 \\
$\mathbf{3 b}$ & 4.2 & 8.3 & 33.3 \\
3c & 4.2 & 12.5 & 37.5 \\
toosendanin & 29.2 & 29.2 & 33.3 \\
blank control & 0.0 & 0.0 & 0.0 \\
\hline
\end{tabular}

${ }^{1}$ The corrected mortality rate was calculated in three different periods (larvae, pupae, and moth). All data (mean \pm $\mathrm{SD})$ are the average of four independent groups (six larvae per group).

Notably, these analogues have good teratogenic activity on three different stages. During the larval period, the symptoms of the larvae of $M$. separata treated by these compounds were slim and wrinkled bodies (not shown). Many larvae molted to malformed pupae or died in the treated groups during the stage of pupation (Figure 3a). Many malformed moths of the treated groups appeared with imperfect wings during the emergence period (Figure $3 b$ ), implying that these analogues might have affected the insect molting hormone [31,32]. These symptoms in the three different periods tested by compounds were consistent with those of fraxinellone funan ring-coupling analogues [19]. This demonstrated that inserting the clopropyl group on C-ring of fraxinellone resulted in more promising analogues.

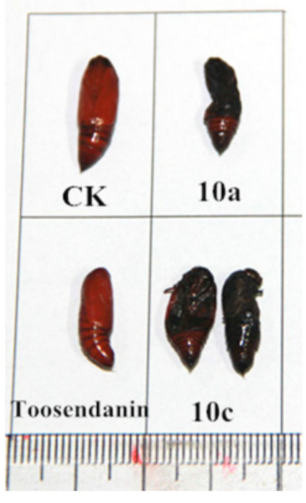

(a)

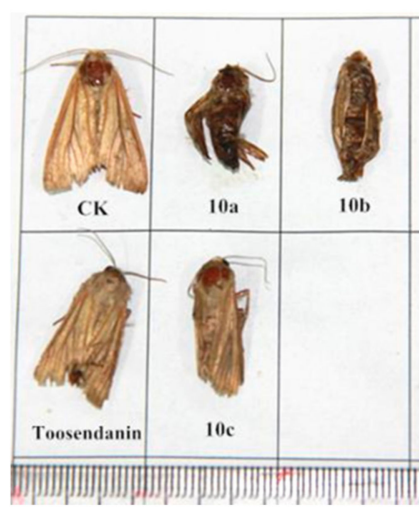

(b)

Figure 3. Representative malformed pictures: (a) Malformed pupae of 3a (10a) and 3c (10c) during the pupation period; (b) malformed moth of $3 \mathbf{a}(10 \mathrm{a}), \mathbf{3 b}(10 \mathrm{~b})$ and $3 \mathbf{c}(10 \mathrm{c})$ during the stage of adult emergence $(\mathrm{CK}=$ blank control group, toosendanin = positive control group). 


\section{Materials and Methods}

\subsection{General}

All NMR spectra were recorded on a Bruker Advance III 500 instrument (Bruker Daltonics Inc., Bremen, Germany) in $\mathrm{CDCl}_{3}$ or $\mathrm{CD}_{3} \mathrm{OD}$ with TMS as internal standard for protons and solvent signals as internal standard for carbon spectra. Chemical shift values are mentioned in $\delta(\mathrm{ppm})$ and coupling constants $(J)$ are given in Hz. HR-ESI-MS spectra were recorded on an AB Sciex 5600 Triple TOF mass spectrometer (AB SCIEX Inc., Singapore). Melting points (m.p.) were determined on an auto-melting point apparatus (Hanon Instruments Co., Ltd., Jinan, China). Column chromatography (CC) was performed over silica gel (200-300 mesh, Qingdao Marine Chemical Ltd.). All reactions were monitored by thin-layer chromatography (TLC) carried out on pre-coated silica gel $\mathrm{GF}_{254}$ plates with a thickness of $0.25 \mathrm{~mm}$ (Qingdao Marine Chemical Group, Co.) with UV light (254 nm and $365 \mathrm{~nm}$ ). All commercial solvents and reagents were freshly purified and dried by standard techniques prior to use. Fraxinellone (1) was isolated from root bark of Dictamnus dasycarpus and established on the basis of extensive spectroscopic analyses, referring to a previous report [19].

\subsection{Synthesis of $\alpha$-Diazocarbonyl Esters $(2 a-2 c)$}

The stirring solution of $1.58 \mathrm{mmol}$ phenylacetate in $20 \mathrm{~mL}$ acetonitrile $(\mathrm{MeCN})$ was added dropwise $379.1 \mathrm{mg}(1.90 \mathrm{mmol})$ of $p$-toluenesulfonyl azide $\left(\mathrm{TsN}_{3}\right)$ in $4 \mathrm{~mL} \mathrm{MeCN}$ at room temperature. Then, $337.48 \mathrm{mg}$ of 1,8-Diazabicyclo[5.4.0]undec-7-ene (DBU) (1.58 mmol) was added and the solution was stirred for $15 \mathrm{~h}$. After monitoring the completion of the reaction by TLC, water was added to terminate the reaction. The reaction solution was extracted with anhydrous ether $(2 \times 30 \mathrm{~mL})$ and the organic phase was dried in anhydrous sodium sulfate $\left(\mathrm{Na}_{2} \mathrm{SO}_{4}\right)$. The organic phase was concentrated in vacuum to give a yellow oil. A silica gel column (300-400 mesh, petroleum ether: ethyl acetate, 40:1-20:1, v/v) was used for column chromatography to obtain the products $\mathbf{2 a - 2}$.

Methyl 2-diazo-2-phenylacetate (2a): yellow solid, 67\% yield. NMR data were consistent with a previous report [29].

Ethyl 2-diazo-2-phenylacetate (2b): yellow solid, 89\% yield. ${ }^{1} \mathrm{H}-\mathrm{NMR}(500 \mathrm{MHz}, \mathrm{MeOD}) \delta 7.54-7.45$ $(\mathrm{m}, 2 \mathrm{H}), 7.39(\mathrm{ddd}, J=8.6,7.4,1.6 \mathrm{~Hz}, 2 \mathrm{H}), 7.19(\mathrm{td}, J=7.4,1.3 \mathrm{~Hz}, 1 \mathrm{H}), 4.32(\mathrm{qd}, J=7.1,1.8 \mathrm{~Hz}, 2 \mathrm{H})$, 1.34 (td, $J=7.1,1.5 \mathrm{~Hz}, 3 \mathrm{H}) ;{ }^{13} \mathrm{C}-\mathrm{NMR}(126 \mathrm{MHz}, \mathrm{MeOD}) \delta 173.49,166.59,130.25,129.90,129.47$ (2C), $126.87,125.11,62.13,49.51,49.34,49.17,49.00,48.83,48.66,48.49,14.76$.

Ethyl 2-(4-bromophenyl)-2-diazoacetate (2c): yellow solid, 88\% yield. ${ }^{1} \mathrm{H}-\mathrm{NMR}\left(500 \mathrm{MHz}, \mathrm{CDCl}_{3}\right) \delta 7.52$ $(\mathrm{dd}, J=8.9,2.4 \mathrm{~Hz}, 1 \mathrm{H}), 7.39(\mathrm{dd}, J=8.9,2.4 \mathrm{~Hz}, 1 \mathrm{H}), 4.37(\mathrm{qd}, J=7.1,1.8 \mathrm{~Hz}, 1 \mathrm{H}), 1.38(\mathrm{td}, J=7.1,1.6$ $\mathrm{Hz}, 2 \mathrm{H}) ;{ }^{13} \mathrm{C}-\mathrm{NMR}\left(126 \mathrm{MHz}, \mathrm{CDCl}_{3}\right) \delta 171.35,165.10,132.31$ (2C), 125.65 (2C), 125.23, 119.58, 77.67, $77.42,77.16,61.50,14.82$.

\subsection{Synthesis of C-Ring Cyclopropyl Analogues (3a-3c) of Fraxinellone}

First, $40 \mathrm{mg}(172.21 \mu \mathrm{mol})$ of fraxinellone (1) and $0.76 \mathrm{mg}(1.72 \mu \mathrm{mol})$ of $\mathrm{Rh}_{2}(\mathrm{OAc})_{4}$ were added into a dry reaction tube sealed with a rubber tap. In the tube, air was replaced four times with argon, and the tube was placed in an ice bath. Then, $378.21 \mu \mathrm{mol}$ phenyldiazoesters (2a-2c) dissolved in $4 \mathrm{~mL}$ of toluene was added dropwise to the tube and stirred in an ice bath for $13 \mathrm{~h}$. After the reaction was monitored for completion by TLC, the solvent was removed directly and the sample was separated in silica gel column chromatography (300-400 mesh, petroleum ether: ethyl acetate, 40:1-10:1, v/v) to afford the analogues $3 \mathbf{a}-\mathbf{3 c}$.

Methyl-4-((1R,7aR)-4,7a-dimethyl-3-oxo-1,3,5,6,7,7a-hexahydroisobenzofuran-1-yl)-6-phenyl-2-oxabicyclo [3.1.0]hex-3-ene-6-carboxylate (3a): white solid, 20\% yield, $\mathrm{R}_{\mathrm{f}}=0.25$ (petroleum ether: EtOAc $=40: 1$ ), m.p. $=141-143^{\circ} \mathrm{C} .{ }^{1} \mathrm{H}-\mathrm{NMR}\left(500 \mathrm{MHz}, \mathrm{CDCl}_{3}\right) \delta 7.33-7.29\left(\mathrm{~m}, 3 \mathrm{H}, \mathrm{H}-2^{\prime \prime}, \mathrm{H}-4^{\prime \prime}\right.$, and H-6"), 7.21 (dd, $\mathrm{J}=7.4,1.9 \mathrm{~Hz}, 2 \mathrm{H}, \mathrm{H}-3^{\prime \prime}$, and H-5") $, 6.05\left(\mathrm{~d}, \mathrm{~J}=0.8 \mathrm{~Hz}, 1 \mathrm{H}, \mathrm{H}-2^{\prime}\right), 5.19\left(\mathrm{~d}, \mathrm{~J}=6.2 \mathrm{~Hz}, 1 \mathrm{H}, \mathrm{H}-5^{\prime}\right), 4.53(\mathrm{~d}$, 
$\mathrm{J}=1.7 \mathrm{~Hz}, 1 \mathrm{H}, \mathrm{H}-8), 3.67$ (s, 3H, $-\mathrm{Me}), 3.18\left(\mathrm{~d}, \mathrm{~J}=5.7 \mathrm{~Hz}, 1 \mathrm{H}, \mathrm{H}-4^{\prime}\right), 2.32(\mathrm{dd}, \mathrm{J}=19.7,6.4 \mathrm{~Hz}, 1 \mathrm{H}, \mathrm{H}-4)$, $2.22(\mathrm{dd}, \mathrm{J}=10.9,7.3 \mathrm{~Hz}, 1 \mathrm{H}, \mathrm{H}-4), 2.14$ (s, 3H, H-10), $2.04(\mathrm{dt}, \mathrm{J}=12.2,3.3 \mathrm{~Hz}, 1 \mathrm{H}, \mathrm{H}-5), 1.81-1.93$ $(\mathrm{m}, 2 \mathrm{H}, \mathrm{H}-5,6), 1.61$ (td, J = 12.9, $3.8 \mathrm{~Hz}, 1 \mathrm{H}, \mathrm{H}-6), 1.02(\mathrm{~s}, 3 \mathrm{H}, \mathrm{H}-11) ;{ }^{13} \mathrm{C}-\mathrm{NMR}\left(126 \mathrm{MHz}, \mathrm{CDCl}_{3}\right)$ $\delta 173.99,169.48,149.04,144.80,131.94,130.03,128.33,128.03,127.35,113.61,84.11,71.29,52.93,42.72$, $39.01,32.83,32.18,28.54,20.77,18.69,18.61$; HR-ESI-MS m/z: Found $403.1496[\mathrm{M}+\mathrm{Na}]^{+}$(calcd for $^{2}$ $\left.\mathrm{C}_{23} \mathrm{H}_{24} \mathrm{NaO}_{5}, 403.1521\right)$.

Ethyl-4-((1R,7aR)-4,7a-dimethyl-3-oxo-1,3,5,6,7,7a-hexahydroisobenzofuran-1-yl)-6-phenyl-2- oxabicyclo[3.1.0] hex-3-ene-6-carboxylate (3b): white solid, 37\% yield, $R_{f}=0.21$ (petroleum ether: EtOAc $=40: 1$ ), m.p. $=$ 144-145 ${ }^{\circ} \mathrm{C} .{ }^{1} \mathrm{H}-\mathrm{NMR}\left(500 \mathrm{MHz}, \mathrm{CDCl}_{3}\right) \delta 7.22-7.15$ ( $\mathrm{m}, 3 \mathrm{H}, \mathrm{H}-2^{\prime \prime}, \mathrm{H}-4^{\prime \prime}$, and $\left.\mathrm{H}-6^{\prime \prime}\right), 7.09(\mathrm{dd}, \mathrm{J}=7.5,1.8$ $\mathrm{Hz}, 2 \mathrm{H}, \mathrm{H}-3^{\prime \prime}$, and $\left.\mathrm{H}-5^{\prime \prime}\right), 5.93\left(\mathrm{~d}, \mathrm{~J}=0.8 \mathrm{~Hz}, 1 \mathrm{H}, \mathrm{H}-2^{\prime}\right), 5.07\left(\mathrm{~d}, \mathrm{~J}=5.7 \mathrm{~Hz}, 1 \mathrm{H}, \mathrm{H}-5^{\prime}\right), 4.41(d, J=1.7 \mathrm{~Hz}, 1 \mathrm{H}$, $H-8), 4.04-3.98(m, 2 H, E t-H), 3.05\left(d, J=5.7 \mathrm{~Hz}, 1 \mathrm{H}, \mathrm{H}-4^{\prime}\right), 2.24-2.09(\mathrm{~m}, 2 \mathrm{H}, \mathrm{H}-4), 2.02(\mathrm{~s}, 3 \mathrm{H}, \mathrm{H}-10)$, $1.92(d t, J=12.2,3.3 \mathrm{~Hz}, 1 \mathrm{H}, \mathrm{H}-5), 1.79-1.66(\mathrm{~m}, 2 \mathrm{H}, \mathrm{H}-5$, and $\mathrm{H}-6), 1.53-1.47(\mathrm{~m}, 1 \mathrm{H}, \mathrm{H}-6), 1.07(t, J=7.1$ $\mathrm{Hz}, 3 \mathrm{H}, \mathrm{Et}-\mathrm{H}), 0.90$ (s, 3H, H-11); ${ }^{13} \mathrm{C}-\mathrm{NMR}\left(126 \mathrm{MHz}, \mathrm{CDCl}_{3}\right) \delta 173.22,169.26,148.69,144.60,131.74$, 130.07, 128.02, 127.67, 127.28, 113.44, 83.97, 70.96, 61.42, 42.54, 38.53, 32.66, 32.00, 28.50, 20.56, 18.49, 18.44, 14.17; HR-ESI-MS m/z: Found 417.1647 [M+Na] (calcd for $\mathrm{C}_{24} \mathrm{H}_{26} \mathrm{NaO}_{5}, 417.1678$ ).

Ethyl-6-(4-bromophenyl)-4-((1R,7aR)-4,7a-dimethyl-3-oxo-1,3,5,6,7,7a-hexahydroisobenzofuran-1-yl)-2- oxabicyclo [3.1.0]hex-3-ene-6-carboxylate (3c): white solid, $10 \%$ yield, $R_{f}=0.30$ (petroleum ether: EtOAc $=30: 1$ ), m.p. $=$ 160-162 ${ }^{\circ} \mathrm{C} .{ }^{1} \mathrm{H}-\mathrm{NMR}\left(500 \mathrm{MHz}, \mathrm{CDCl}_{3}\right) \delta 7.48\left(d, J=7.5 \mathrm{~Hz}, 2 \mathrm{H}, \mathrm{H}-3^{\prime \prime}\right.$, and $\left.\mathrm{H}-5^{\prime \prime}\right), 7.37(d, J=7.9 \mathrm{~Hz}$, $2 \mathrm{H}, \mathrm{H}-2^{\prime \prime}$, and $\left.\mathrm{H}-6^{\prime \prime}\right), 5.81\left(\mathrm{~s}, 1 \mathrm{H}, \mathrm{H}-\mathrm{2}^{\prime}\right), 5.11\left(\mathrm{~d}, \mathrm{~J}=5.5 \mathrm{~Hz}, 1 \mathrm{H}, \mathrm{H}-5^{\prime}\right), 4.33(\mathrm{~s}, 1 \mathrm{H}, \mathrm{H}-8), 4.08-4.03(\mathrm{~m}, 2 \mathrm{H}$, $E t-H), 3.37\left(d, J=5.5 \mathrm{~Hz}, 1 \mathrm{H}, \mathrm{H}-4^{\prime}\right), 2.23(d d, J=19.8,6.4 \mathrm{~Hz}, 1 \mathrm{H}, \mathrm{H}-4$, and $\mathrm{H}-10), 2.12-2.05(\mathrm{~m}, 4 \mathrm{H}, \mathrm{H}-4$, and $H-10), 1.81-1.61(m, 3 H, H-5$, and $H-6), 1.30(d d, J=14.4,7.3 \mathrm{~Hz}, 1 \mathrm{H}, \mathrm{H}-6), 1.13(t, J=7.1 \mathrm{~Hz}, 3 \mathrm{H}$, Et-H), 1.06 (s, 3H, H-11 ); ${ }^{13} \mathrm{C}-\mathrm{NMR}\left(126 \mathrm{MHz}, \mathrm{CDCl}_{3}\right) \delta 172.75,170.04,148.98,143.71,132.03,129.74$, $129.37,127.14,121.73,115.17,83.22,70.64,61.79,44.45,40.19,32.34,31.29,28.08,20.44,18.65,18.17,14.36$; HR-ESI-MS m/z: Found 495.0762 [M+Na] (calcd for $\mathrm{C}_{24} \mathrm{H}_{25} \mathrm{BrNaO}_{5}, 495.0783$ ).

\subsection{X-Ray Experimental of $3 a$}

Single crystals of $3 \mathbf{a}\left(\mathrm{C}_{23} \mathrm{H}_{24} \mathrm{O}_{5}\right)$ were obtained by recrystallization in ethanol. A suitable crystal was selected and analyzed on a SuperNova, Dual, $\mathrm{Cu}$ at zero, Eos diffractometer (Bruker Daltonics Inc., Bremen, Germany). The crystal was kept at 293(2) K during data collection. Using Olex2 [33], the structure was solved with the Superflip [34] structure solution program using charge flipping and refined with the ShelXL [35] refinement package using least squares minimisation.

\subsection{The Insecticidal Activity Assay}

The insecticidal activity of $\mathbf{3 a}-\mathbf{3} \mathbf{c}$ was tested as the mortality rate using the leaf-dipping method against the pre-third-instar larvae of $M$. separata using the reported procedure [30,36]. Briefly, 24 pre-third-instar larvae (6 larvae per group) were used for each sample. Each treatment was performed four times. Acetone solutions of samples and toosendanin (positive control) were prepared at $1 \mathrm{mg} / \mathrm{mL}$. Fresh wheat leaf discs $(1 \times 1 \mathrm{~cm})$ were dipped into the corresponding solution for $3 \mathrm{~s}$, then taken out and dried. Several pieces of treated leaf discs were kept in each six-well plate, which was then placed in a conditioned room $\left(25 \pm 2{ }^{\circ} \mathrm{C}, 65-80 \%\right.$ relative humidity $(\mathrm{RH}), 12 \mathrm{~h} / 12 \mathrm{~h}$ (light/dark). After two days, untreated fresh leaves were added to the all dish until the adult pupae emergence. The corrected mortality rates of the tested compounds against $M$. separata Walker were calculated in three different periods by the following formula:

$$
\text { corrected mortality rate }(\%)=\frac{\text { mortality rate of test }- \text { mortality rate of control }}{100 \%-\text { mortality rate of control }} \times 100 \%
$$

\section{Conclusions}

Natural-product analogues attract extensive attention because of their high hit rate in the process the discovery of new drugs. To enrich the fraxinellone-based structures, we semi-synthesized 
C-ring-modified cyclopropyl analogues by $\mathrm{Rh}(\mathrm{II})$-catalyzed cyclopropanation for the first time. Notably, this cyclopropanation of fraxinellone provided products with orienting cyclopropyl ring in $\beta$ configuration and ester group on the convex face of the bicycle, but without altering other functional groups. Although their yield is not high, the reaction applied the synthetic strategy for modification of diverse furan-containing NPs. An evaluation of insecticidal activity showed that $3 \mathrm{c}$ displayed stronger insecticidal activity than parental counterpart and toosendanin. Their corresponding pharmacological data and target of action are undergoing.

Supplementary Materials: The following are available online, Figure S1-S5: NMR spectra of compounds 2b, 2c, and 3a-3c; Figure S6-S8: HR-ESI-MS spectra of compounds 3a-3c; Table S1: Crystal data and structure refinement for $3 a$.

Author Contributions: Conceptualization, X.-J.Y. and J.-J.T.; methodology, Q.-M.D. and M.-R.W.; validation, X.-J.Y., Q.M.D., and J.-J.T.; formal analysis, J.-J.T.; investigation, M.-R.W. and Q.M.D.; resources, X.-J.Y.; data curation, Q.M.D.; writing - original draft preparation, X.-J.Y.; writing—review and editing, J.-J.T.; supervision, J.-J.T.; project administration, X.-J.Y.; funding acquisition, X.-J.Y. All authors have read and agreed to the published version of the manuscript.

Funding: This research was funded by the National Natural Science Foundation of China (31860089), Yangling Demonstration Zone Science and Technology Plan Project (2017NY-07), China and Science and Technology Department of Shaanxi Province (2019JM-516).

Acknowledgments: This work was given some technical support by Instrument Shared Platform of Northwest A\&F University.

Conflicts of Interest: The authors declare no conflict of interest.

\section{References}

1. Machida, S.; Mukai, S.; Kono, R.; Funato, M.; Saito, H.; Uchiyama, T. Synthesis and comparative structure-activity study of carbohydrate-based phenolic compounds as alpha-glucosidase inhibitors and antioxidants. Molecules 2019, 24, 4340. [CrossRef] [PubMed]

2. Richers, J.; Pothig, A.; Herdtweck, E.; Sippel, C.; Hausch, F.; Tiefenbacher, K. Synthesis and neurotrophic activity studies of illicium sesquiterpene natural product analogues. Chem.-Eur. J. 2017, 23, 3178-3183. [CrossRef] [PubMed]

3. Liao, L.-X.; Song, X.-M.; Wang, L.-C.; Lv, H.-N.; Chen, J.-F.; Liu, D.; Fu, G.; Zhao, M.-B.; Jiang, Y.; Zeng, K.-W.; et al. Highly selective inhibition of IMPDH2 provides the basis of antineuroinflammation therapy. Proc. Natl. Acad. Sci. 2017, 114, E5986-E5994. [CrossRef] [PubMed]

4. Cantrell, C.L.; Dayan, F.E.; Duke, S.O. Natural products as sources for new pesticides. J. Nat. Prod. 2012, 75, 1231-1242. [CrossRef]

5. Bolzani Vda, S.; Davies-Coleman, M.; Newman, D.J.; Singh, S.B.; Gordon, M.; Cragg, D.; Phil, D. Sc. (h.c.): A man for all natural products. J. Nat. Prod. 2012, 75, 309-310. [CrossRef]

6. $\mathrm{Xu}, \mathrm{H}$. Natural products as leads for new drugs and pesticides discovery. Mini Rev. Org. Chem. 2012, 9, 125. [CrossRef]

7. Fuse, S.; Matsumura, K.; Johmoto, K.; Uekusa, H.; Tanaka, H.; Hirose, T.; Sunazuka, T.; Omura, S.; Takahashi, T. The design, synthesis, and evaluation of 1,5,7-trisubstituted-3-pyridyl-xanthones for use as insecticides starting from pyripyropene A. Chem.-Eur. J. 2016, 22, 18450-18455. [CrossRef]

8. Copping, L.G.; Duke, S.O. Natural products that have been used commercially as crop protection agents. Pest. Manag. Sci. 2007, 63, 524-554. [CrossRef]

9. Newman, D.J.; Cragg, G.M. Natural products as sources of new drugs from 1981 to 2014. J. Nat. Prod. 2016, 79, 629-661. [CrossRef]

10. Liu, Z.L.; Ho, S.H.; Goh, S.H. Effect of fraxinellone on growth and digestive physiology of Asian corn borer, Ostrinia furnacalis Guenee. Pestic. Biochem. Physiol. 2008, 91, 122-127. [CrossRef]

11. Liu, Z.L.; Ho, S.H.; Goh, S.H. Modes of action of fraxinellone against the tobacco budworm, Heliothis virescens. Insect Sci. 2009, 16, 147-155. [CrossRef]

12. Zhao, W.; Wolfender, J.L.; Hostettmann, K.; Xu, R.; Qin, G. Antifungal alkaloids and limonoid derivatives from Dictamnus dasycarpus. Phytochemistry 1998, 47, 7-11. [CrossRef] 
13. Riley, A.P.; Day, V.W.; Navarro, H.A.; Prisinzano, T.E. Palladium-catalyzed transformations of salvinorin A, a neoclerodane diterpene from Salvia divinorum. Org. Lett. 2013, 15, 5936-5939. [CrossRef] [PubMed]

14. Harding, W.W.; Schmidt, M.; Tidgewell, K.; Kannan, P.; Holden, K.G.; Dersch, C.M.; Rothman, R.B.; Prisinzano, T.E. Synthetic studies of neoclerodane diterpenes from Salvia divinorum: Selective modification of the furan ring. Bioorg. Med. Chem. Lett. 2006, 16, 3170-3174. [CrossRef] [PubMed]

15. Riley, A.P.; Groer, C.E.; Young, D.; Ewald, A.W.; Kivell, B.M.; Prisinzano, T.E. Synthesis and kappa-opioid receptor activity of furan-substituted salvinorin A analogues. J. Med. Chem. 2014, 57, 10464-10475. [CrossRef] [PubMed]

16. Chen, W.; Isman, M.B.; Chiu, S.F. Antifeedant and growth-inhibitory effects of the limonoid toosendanin and melia-toosendan extracts on the variegated cutworm, Peridroma-Saucia (Lep, Noctuidae). J. Appl. Entomol. 1995, 119, 367-370. [CrossRef]

17. Shi, Y.L.; Wang, W.P.; Liao, C.Y.; Chiu, S.F. Effect of toosendanin on the sensory inputs of chemoreceptors of the armyworm larvae Mythimna-Separata. Acta Entomol. Sin. 1986, 29, 233-238.

18. Guo, Y.; Qu, H.; Zhi, X.Y.; Yu, X.; Yang, C.; Xu, H. Semisynthesis and insecticidal activity of some fraxinellone derivatives modified in the B ring. J. Agric. Food Chem. 2013, 61, 11937-11944. [CrossRef]

19. Dong, Q.M.; Dong, S.; Shen, C.; Cao, Q.H.; Song, M.Y.; He, Q.R.; Wang, X.L.; Yang, X.J.; Tang, J.J.; Gao, J.M. Furan-site bromination and transformations of fraxinellone as insecticidal agents against Mythimna separata Walker. Sci. Rep. 2018, 8, 8372. [CrossRef]

20. Xiang, P.; Cao, Q.H.; Dong, Q.M.; Yang, X.J.; Tang, J.J.; Bai, H. Furan-site transformations of obacunone as potent insecticidal agents. Heliyon 2018, 4, e01064. [CrossRef]

21. Wang, D.M.; Zhang, C.C.; Zhang, Q.; Shafiq, N.; Pescitelli, G.; Li, D.W.; Gao, J.M. Wightianines A-E, Dihydro-beta-agarofuran sesquiterpenes from Parnassia wightiana, and their antifungal and insecticidal activities. J. Agric. Food Chem. 2014, 62, 6669-6676. [CrossRef] [PubMed]

22. Fan, N.J.; Wei, S.P.; Gao, J.M.; Tang, J.J. Potential insecticidal activity of steroidal C-17 pyrazolinyl derivatives. J. Braz. Chem. Soc. 2015, 26, 389-392. [CrossRef]

23. Xiao, J.; Zhang, Q.; Gao, Y.Q.; Tang, J.J.; Zhang, A.L.; Gao, J.M. Secondary metabolites from the endophytic Botryosphaeria dothidea of Melia azedarach and their antifungal, antibacterial, antioxidant, and cytotoxic activities. J. Agric. Food Chem. 2014, 62, 3584-3590. [CrossRef] [PubMed]

24. Zhang, X.Y.; Shen, J.; Zhou, Y.; Wei, Z.P.; Gao, J.M. Insecticidal constituents from Buddlej aalbiflora Hemsl. Nat. Prod. Res. 2017, 31, 1446-1449. [CrossRef]

25. Wenkert, E.; Khatuya, H. The effect of substituents of alpha-alkyl sidechains on furan-diazoester interactions. Tetrahedron Lett. 1999, 40, 5439-5442. [CrossRef]

26. Wenkert, E.; Khatuya, H.; Klein, P.S. Reactions of ethyl diazoacetate with beta-methylfurans. Tetrahedron Lett. 1999, 40, 5171-5174. [CrossRef]

27. Lindsay, V.N.G.; Lin, W.; Charette, A.B. Experimental evidence for the all-up reactive conformation of chiral rhodium(II) carboxylate catalysts: Enantioselective synthesis of cis-cyclopropane alpha-amino acids. J. Am. Chem. Soc. 2009, 131, 16383-16385. [CrossRef]

28. Liao, K.B.; Pickel, T.C.; Oyarskikh, V.B.; Acsa, J.B.; Usaev, D.G.M.; Davies, H.M.L. Site-selective and stereoselective functionalization of non-activated tertiary C-H bonds. Nature 2017, 551, 609-613. [CrossRef]

29. Lehner, V.; Davies, H.M.L.; Reiser, O. Rh(II)-catalyzed cyclopropanation of furans and its application to the total synthesis of natural product derivatives. Org. Lett. 2017, 19, 4722-4725. [CrossRef]

30. Xu, H.; He, X.Q. Natural products-based insecticidal agents 6. Design, semisynthesis, and insecticidal activity of novel monomethyl phthalate derivatives of podophyllotoxin against Mythimna separata Walker in vivo. Bioorg. Med. Chem. Lett. 2010, 20, 4503-4506. [CrossRef]

31. Guo, Y.; Yan, Y.Y.; Yu, X.; Wang, Y.; Zhi, X.Y.; Hu, Y.; Xu, H. Synthesis and insecticidal activity of some novel fraxinellone-based esters. J. Agric. Food Chem. 2012, 60, 7016-7021. [CrossRef] [PubMed]

32. Guo, Y.; Yan, Y.Y.; Yang, C.; Yu, X.; Zhi, X.Y.; Xu, H. Regioselective synthesis of fraxinellone-based hydrazone derivatives as insecticidal agents. Bioorg. Med. Chem. Lett. 2012, 22, 5384-5387. [CrossRef] [PubMed]

33. Dolomanov, O.V.; Bourhis, L.J.; Gildea, R.J.; Howard, J.A.; Puschmann, H. OLEX2: A complete structure solution, refinement and analysis program. J. Appl. Crystallogr. 2009, 42, 339-341. [CrossRef]

34. Palatinus, L.; Chapuis, G. SUPERFLIP-a computer program for the solution of crystal structures by charge flipping in arbitrary dimensions. J. Appl. Crystallogr. 2007, 40, 786-790. [CrossRef] 
35. Sheldrick, G.M. A short history of SHELX. Acta Crystallogr. Sect. A 2007, 64, 112-122. [CrossRef]

36. Tang, J.J.; Zhang, F.Y.; Wang, D.M.; Tian, J.M.; Dong, S.; Gao, J.M. Semisynthesis and antifeedant activity of new derivatives of a dihydro-beta-agarofuran from Parnassia wightiana. Int. J. Mol. Sci. 2013, 14, 19484-19493. [CrossRef]

Sample Availability: Samples of the compounds are available from the authors.

(C) 2020 by the authors. Licensee MDPI, Basel, Switzerland. This article is an open access article distributed under the terms and conditions of the Creative Commons Attribution (CC BY) license (http://creativecommons.org/licenses/by/4.0/). 